\title{
LINGUO-COGNITIVE AND LINGUO-CULTURAL ANALYSIS OF THE ENGLISH PHRASEOLOGICAL UNITS WITH THE FIRE COMPONENT
}

\author{
CMirjalilova M., ORCID: 0000-0002-5752-5399, Uzbek state world languages university, \\ Tashkent, Uzbekistan, Madino4ka0993@mail.ru
}

\section{ЛИНГВО-КОГНИТИВНЫЙ И ЛИНГВО-КУЛЬТУРНЫЙ АНАЛИЗ АНГЛИЙСКИХ ФРАЗЕОЛОГИЧЕСКИХ ЕДИНИЦ С КОМПОНЕНТОМ «ОГОНЬ»}

\author{
CМиржсалилова M., ORCID: 0000-0002-5752-5399, Узбекский государственный \\ университет мировых языков, г. Ташкент, Узбекистан, Madino4ka0993@mail.ru
}

Abstract. At present, special attention is paid in the cognitive linguistics to the problem of linguistic units that represent different knowledge structures. Phraseological units, being one of the core linguistic means of verbalization of different knowledge structures, are ought to be analyzed thoroughly. Further to this, idiomatic expressions and proverbs are vital signals in verbalization of cultural values and national specific concepts which leads to the necessity of linguo-cultural analysis of these units. This article is aimed to analyze phraseological units with the fire component in English language according to cultural and cognitive parameters and to identify cultural values and cognitive models that are presented by these expressions.

Аннотащия. В настоящее время в когнитивной лингвистике особое внимание уделяется проблеме языковых единиц, представляющих различные структуры знаний. Фразеологические единицы, являющиеся одним из основных языковых средств вербализации различных структур знаний, должны быть тщательно проанализированы. В дополнение к этому, идиоматические выражения и пословицы являются жизненно важными сигналами в вербализации культурных ценностей и национальных специфических концепций, что приводит к необходимости лингвокультурного анализа этих единиц. Целью данной статьи является анализ фразеологизмов с компонентом «огонь» в английском языке по культурным и когнитивным параметрам, а также выявление культурных ценностей и когнитивных моделей, представленных этими выражениями.

Keywords: natural phenomenon, phraseological units, cultural values, knowledge structures, cognitive models, metaphor.

Ключевые слова: феномен природы, фразеологизмы, культурные ценности, структуры знаний, когнитивные модели, метафора.

The role of phraseological units in verbalization of different knowledge structures is, by no means, vital in cognitive linguistics. Especially, phraseological units with the component of natural phenomena serve as a huge bank of culture specific and historically marked knowledge structures representation. The usage of natural phenomena at this level of linguistics is observed in many languages as these types of language units hold particular national-cultural codes and cognitive models. The concept "natural phenomenon" itself comprises of a great number of micro-concepts, for this reason, in this article we intend to analyze one of these concepts, "fire". As a source for the 
research, we took different monolingual, etymological, associative and phraseological dictionaries of English language. Overall number of analyzed phraseological units is 43 with the samples of proverbs too.

In Linguo-culturology, phraseological units are studied broadly because they represent cultural and national specific values. According to N. F. Alefirenko, the following types of cultural values are widely represented in the language [1]:

Vital: life, health, living, environment;

Social: social status, profession, wealth, gender equality, tolerance;

Political: freedom, democracy, lawfulness, peace;

Religious: God, faith, sacred laws, salvation, blessing;

Moral: goodness, kindness, friendship, honour, decency;

Aesthetic: beauty, ideal, harmony, lifestyle.

According to the cultural parameters, we grouped the phraseological units to the ones that political, religious and moral values. The first group of phraseological units verbalizes the concept "criticism" and this notion can be understood as the violation of social and moral values. Examples are come under fire, draw fire, Kentish fire, a running fire. In all of these examples, connotative meaning of the word "fire" means "criticism". They mean to be criticized or to make harsh criticism towards someone, and by no means, these types of situation in many cultures are considered negatively $[1,3]$.

There is also an idiom "keep the home fires burning" which seems to represent both vital and moral values of mankind. In this context, the meaning of fire means daily routine necessities of a family, the things that are crucial for life. The whole idiom means to maintain daily routine and provide the necessities of life in a home. From the moral point of view, this is responsibility of any mature individual towards his or her family. So, we could observe both vital and moral values representation in this phraseological unity. Also, other examples "put someone's bacon out of fire", "put out a fire" refer to keeping or saving someone from trouble or misfortune, to back your friends up. These are also examples of moral values [4].

These cultural values can be subdivided into universal, national, group, family, individual [2]. From our examples, we could refer phraseological units as "Kentish fire" (verbalization of strong disagreement towards some ideas), "to put the Thames on fire" (to make something unbelievable), "with fire and sword" as bright samples of representation of national specific values of Great Britain. In these examples, we could observe names of places that are located in this area, but sometimes not all phraseological units may have these kinds of bright examples, sometimes, a reader should know cultural values of a particular nation broadly in order to find national specific information. "Keep the home fires burning" can be an example, as the first usage of this phrase was observed in the song composed in 1914 by Ivor Novello. It was a British patriotic song that touched war concepts. After this song, this phrase became an idiom and remained in English language [5].

The study of phraseological units is widely promoted in cognitive linguistics also. In Cognitive Linguistics, a special attention is provided for the problem of knowledge structures classification and the means of their representation. So far, different scholars have given various classifications of knowledge structures, but in cognitive linguistics the most accepted one differentiates these types:

Linguistic (lexicon, grammar, phonetics word-formation, etc.);

Encyclopedic (knowledge about the world, history, politics, economies, nature, etc.);

Communicative (knowledge of communicative aims and intentions, conditions and circumstances of communication, behavior norms and aims of different speech acts); 
Cultural (knowledge about literature, art, cultural values, customs and traditions, religion, mythology and beliefs, etc.).

It has long been acknowledged that phraseology of any language reflects people's culture, history, national mentality and life style [3]. Therefore phraseological units by their very nature are intended to convey knowledge structures related to all spheres of life. From this position phraseological units can be subdivided into specific groups representing religious, mythological, literary, historical knowledge structures. In the phraseological units "fire and brimstone" (hell and afterlife punishment"), "go through fire and water" (to undergo great difficulties or dangers) we can observe the representation of religious knowledge structures (taken from Bible). Another example, "Promethean fire" means nonstop pursuit of power and authority. This expression represents mythological knowledge structure and connotative meaning is related to the myth of the God Promethean who stole the torch of fire from Zeus [6].

Besides representing different knowledge structures, phraseological units are also studied in the sphere of conceptual metaphor theory. This theory is rather new term in the modern linguistic trends but it is widely studied by different scholars. Conceptual Metaphor Theory was first proposed by G. Lacoff and M. Johnson in their revolutionary work "Metaphors We Live By" and since then has been developed and elaborated in a number of subsequent researches. The basic principle of Conceptual Metaphor Theory is that metaphor is not simply a stylistic device: it is a way of thinking, a tool of cognition. Metaphor operates at the level of thinking as "our conceptual system is largely metaphorical, and our ordinary conceptual system, in terms of which we both think and act, is fundamentally metaphorical in nature" (Lacoff, Johnson, 1980, p.3). Linguists in Cognitive Linguistics claim that components of phraseological units are interrelated metaphorically in our mind and cognition. In our case, analysis of the phraseological units with the component of "fire" show that examples are mainly obtain metaphorical character, despite some non-metaphorical relations too [7].

For the analysis, cognitive models of phraseological units are represented in the form of gestalt, where there is a source domain and target domain. A source domain is the concept "fire", while target domains, after analysis, are related to political, social, situational and other phenomena. For example, we find the cognitive model "FIRE-PASSION" in the following expressions: "burn like fire", "fire and fury", "fire that is closest kept burns most of all", "a fire in the blood", "on fire". Another model is "FIRE-CRITICISM" which was observed in the samples: "come under fire", "draw fire". "a running fire", "piss on someone's bonfire", "Kentish fire". Lastly mentioned phraseological units comprise both moral and political, social issues. That's why, we can tall that natural phenomenon fire is associated with a social issue.

The phraseological units "hang fire", "hold fire", "like a forest fire", "on the fire" are samples of cognitive model "FIRE-TIME (PERIOD)". "Draw fire from somebody", "direct one's fire from somebody", "build a fire under somebody", "drive out fire with fire", "one fire drives out another", "open fire", "play with fire", "with fire and sword" are actual examples of the cognitive model "FIRE-WAR". From this it can be said that "fire" as a concept may have metaphorical meanings in the sphere of politics, social relationships, can describe time scale, emotions and tools of fight in phraseology.

As a result of cultural and cognitive analysis of phraseological units with the component of fire, it has been concluded that the concept fire in English language is associated with both positive and negative connotations, the last being more observed in mental process of knowledge sturctures verbalization and in the process of encoding cultural codes [8]. 
References:

1. Evans, V. (2006). Cognitive linguistics. Edinburgh University Press. (in Russian).

2. Lakoff, Dzh., \& Dzhonson, M. (2008). Metafory, kotorymi my zhivem. Moscow. (in Russian).

3. Matveeva, G. G., Lenets, A. V., \& Petrova, E. I. (2013). Osnovy pragmalingvistiki. Moscow. (in Russian).

4. Popova, Z. D., \& Sternin, I. A. (2007). Kognitivnaya lingvistika. Moscow. (in Russian).

5. Maslova, V. A. (2004). Kognitivnaya lingvistika. Moscow. (in Russian).

6. Ashurova, D. U., \& Galieva, M. R. (2013). Stylistics of Literary Text. Tashkent.

7. Maslova, V. A. (2004). Lingvokul'turologiya. Moscow. (in Russian).

8. Kunin, A. V. (1984). Anglo-russkij frazeologičeskij slovar': English-Russian phraseological dictionary. Russkij jazyk.

\section{Список литературь:}

1. Evans V. Cognitive linguistics. Edinburgh University Press, 2006.

2. Лакофф Дж., Джонсон М. Метафоры, которыми мы живем. М., 2008.

3. Матвеева Г. Г., Ленец А. В., Петрова Е. И. Основы прагмалингвистики. М., 2013.

4. Попова 3. Д., Стернин И. А. Когнитивная лингвистика. М.: Восток Запад, 2007.

5. Маслова В.А. Когнитивная лингвистика. М., 2004.

6. Ashurova D. U., Galieva M. R. Stylistics of Literary Text. Tashkent. 2013.

7. Маслова В. А. Лингвокультурология. М., 2004.

8. Kunin A. V. Anglo-russkij frazeologičeskij slovar': English-Russian phraseological dictionary. Russkij jazyk, 1984.

Работа поступила

в редакиию 08.03.2020 г.
Принята к публикации

11.03.2020 2.

Ссылка для циитирования:

Mirjalilova M. Linguo-cognitive and Linguo-cultural Analysis of the English Phraseological Units With the Fire Component // Бюллетень науки и практики. 2020. Т. 6. №4. С. 532-535. https://doi.org/10.33619/2414-2948/53/64

Cite as (APA):

Mirjalilova, M. (2020). Linguo-cognitive and Linguo-cultural Analysis of the English Phraseological Units With the Fire Component. Bulletin of Science and Practice, 6(4), 532-535. https://doi.org/10.33619/2414-2948/53/64 